\title{
Short communication: Heterosis and combining ability of Nepalese yellow maize (Zea mays L.)
}

\author{
S R Gautam ${ }^{1}$, BR Ojha ${ }^{1}$, SK Ghimire ${ }^{1}$, and DB Gurung ${ }^{2}$ \\ ${ }^{1}$ Institute of Agriculture and Animal Science, Rampur, Chitwan, Nepal \\ ${ }^{2}$ National Maize Research Program, Rampur, Chitwan, Nepal
}

Nepalese yellow maize inbred lines were characterized for general combining ability (GCA) and specific combining ability (SCA) of their crosses and parents were identified having high combining ability for determining the heterotic effects on yield and other quantitative traits of hybrids. A line $\mathrm{x}$ tester mating design was used for making the crosses in the winter season of 2008 and the hybrids along with their parents and four checks were evaluated in Randomized Complete Block Design (RCBD) with three replications in the spring season of 2009 at the experimental farm of the National Maize Research Program, Chitwan. Significant variations were found among the treatments for grain yield and other traits which indicated presence of high magnitude of genetic variations among tested inbred lines. The cross between RML-32 and RML-17 produced the highest grain yield (15870 kg/ha) among the crosses. Hybrids such as RL-194 x RL-84 (10770 kg/ha), RML-21 x RML-17 (9270 kg/ha), RL-180 x RML-17 (9270 kg/ha) and L-1 x RL-84 (8785 kg/ha) were found superior grain yielder. Thirty-nine hybrids showed positive mid-parent heterosis for grain yield among 40 crosses. The highest positive mid-parent heterosis for grain yield was found $880 \%$ in cross between RML-32 and RML-17, followed by RL-98X RML-17 (507\%), RL-103 x RML-17 (403\%), PUTU-18 x RML- 17 (351\%) and RL-180 x RL 84 (316\%).

Key words : heterosis, GCA, SCA, maize

\section{Introduction}

In Nepal, maize being the second most important staple food commodity after rice both in area and production agriculture and economy and covers nearly $80 \%$ of the hill area. It is estimated that for the next two decades the overall demand for maize will be increased by $6-8 \%$ per annum largely as result of the increased demand for food in hill and feed in terai and inner-terai (Adhikari, 2007). The increasing demand of maize especially in the terai or accessible areas increasing justify the research work on hybrid maize variety development and hybrid technology would definitely curtail the import of maize grain for animal feeds. The production and productivity of maize per unit area must be increased in order to feed the ever-growing population of Nepal. One of the viable alternatives to increase the productivity of maize is to develop hybrids. The yield of hybrids is generally more than $30 \%$ as compared to improved open pollinated varieties. In addition, hybrids are most resistant to disease and insect pests and are more uniform in terms of plant height, maturity and other important agronomic traits (Gurung, 2006). National Maize Research Program (NMRP) in Nepal has so far developed and released 23 improved open pollinated varieties of which one variety was a hybrid Gaurav which failed to be accepted by the farmers because of premature release of this hybrid. There was difficult to maintain inbred of Gaurab which made it impossible to produce F1 seeds. Considering the demand of hybrids, NMRP has started its efforts since 1987 to develop conventional hybrids (Sharma, 2003). In recent year; maize is emerging as an industrial crop in accessible areas in the terai. Farmers have been growing Indian hybrids since many years. Hybridization is the most potent technique for breaking yield barriers and developing varieties having desirable quantitative and qualitative traits. The selection of suitable parents for 
hybridization is one of the most important steps in hybridization. The information on the heterosis and combining ability of inbred lines is essential for systematic hybrid research program.

The information on combining ability and heterosis of Nepalese germplasm is limited. Information on quantitative characters in terms of general and specific combining ability for a set of parents can be obtained from line $\mathrm{x}$ tester analysis. Heterosis and combining ability study of maize genotypes provides a new avenue in the Nepal and in the world. Considering this, the present investigation was, therefore, conducted to evaluate twenty two inbred lines, their $\mathrm{F}_{1}$ crosses compared with checks (Arun-2, Rampur composite, Nepali Hybrid Gaurav and Indian Hybrid (Bioseed-9681) for their grain yield and other quantitative characters aiming to : characterize maize inbred lines based on qualitative and quantitative traits, estimate the general and specific combining ability of maize inbred lines and their crosses, identify the parents with high combining ability and determine the heterotic effects on yield and other quantitative traits in $\mathrm{F}_{1}$ hybrids.

\section{Materials and methods}

The experiment was carried out in September 2008 in the first year and the evaluation of crosses was done from February to June of 2009 in the second year. The experiments were conducted at National Maize Research Program (NMRP) farm, Rampur, Chitwan, which is situated in the inner terai region of Nepal. Geographically, it is located at $27.40^{\circ} \mathrm{N}$ latitude, $84.19^{\circ} \mathrm{E}$ longitude and at an altitude of $228 \mathrm{~m}$. The climate of the experimental site lies in humid sub-tropical region. Twenty inbred lines for females, two inbred lines for testers and also four check varieties namely Gaurav hybrid, Arun-2, Indain Hybrid (Bioseed 9681) and Rampur Composite were also obtained from NRMP, Rampur, Chitwan for the experiment.

A crossing block was prepared in September, 2008 for winter season. Line tester mating design was followed for making forty cross combinations using two testers and twenty female inbred lines. Staggered planting dates (three dates of sowings) were carried out for testers in order to ensure synchronized flowering between lines and testers at five days interval at 2008, september-1, September-6 and September-11. Female were sown in September, 6, 2008. Seeds were planted in four rows of $5-\mathrm{m}$ length and spaced $75 \mathrm{~cm} \times 25 \mathrm{~cm}$ between the two rows and $25 \mathrm{~cm}$ between hills. Two seeds per hill were planted with the help of planter. The 4 rows of net area of each plot of $5 \mathrm{~m}$ length, $75 \mathrm{~cm} \times 25 \mathrm{~cm}$ spacing with net area $15 \mathrm{~m}^{2}$. In crossing block, selection of parents in the field, bagging of ear and tassel, pollination, tagging/labeling, characterization of inbred lines on leaf, stem, anther, tassel and silk color were done systematically. Chlorophyll measurement was done in the same leaf in without destruction over the crop cycle. Area under SPAD value retreat curve (AUSRC) was calculated using the following formula- AUSRC $=\sum[\{\mathrm{S} 1+\mathrm{S} 2 / 2\}](\mathrm{Ti}+1-\mathrm{Ti})$.

In spring season, the crosses or progenies were evaluated along with their parents and 4 checks in evaluation block which were planted at February 11, 2009. The total numbers of treatments were 66 which were obtained as $40 \mathrm{~F} 1$ 's $\{20 \mathrm{x} 2$ cross (line $\mathrm{x}$ testers) $\}, 20$ female parent inbred lines, 2 testers and 4 check varieties (Gaurav Nepali Hybrid, Rampur Composite, Arun-2 and Indian Hybrid,Bioseed-9681). 
Table 1. Details of inbred lines and check varieties at Rampur, Chitwan in 2008/09

\begin{tabular}{|c|c|c|c|}
\hline S.N. & Name of inbred lines & Country of origin & Parentage /source \\
\hline 1 & RL 17 & Nepal & - \\
\hline 2 & RL 100 & Nepal & Upahar \\
\hline 3 & RL 36 & Nepal & - \\
\hline 4 & RL 21 & Nepal & - \\
\hline 5 & RL 103 & Nepal & Upahar \\
\hline 6 & RL 98 & Nepal & Upahar \\
\hline 7 & RL 94 & Nepal & Upahar \\
\hline 8 & RL 107 & Nepal & Upahar \\
\hline 9 & RL 194 & Nepal & Pool 21 \\
\hline 10 & RL 180 & Nepal & Pool 21 \\
\hline 11. & RML41 & CIMMYT Mexico & CML 421 \\
\hline 12. & RML5 & CIMMYT Mexico & CA00314 \\
\hline 13. & RML24 & CIMMYT Mexico & CML 431 \\
\hline 14. & RML64 & CIMMYT Mexico & CML 285 \\
\hline 15. & RML32 & CIMMYT Mexico & CA00320 \\
\hline 16. & L1(=RL201) & Thailand & - \\
\hline 17. & L5(=RL205) & Thailand & - \\
\hline 18. & L20(=RL220) & Thailand & - \\
\hline 19. & PUTU16(=RL241) & Thailand & - \\
\hline 20. & PUTU18(=RL243) & Thailand & - \\
\hline 21. & RL 84 (Tester) & Nepal & Upahar \\
\hline 22. & RML 17 (Tester) & CIMMYT Mexico & CML 287 \\
\hline- & Arun-2 (check) & Nepal & Uncac 242 x Amaril 59 \\
\hline - & Gaurav (Check) & Nepal NML-1(=CML 433) & $\begin{array}{l}(\mathrm{CML} \quad 433=\mathrm{KTX} 3753) \quad X \\
(\mathrm{CML} 430=\mathrm{AM}\end{array}$ \\
\hline- & $\begin{array}{l}\text { Rampur composite } \\
\text { (Check) }\end{array}$ & Nepal & Thai composite $x$ Suwan- 1 \\
\hline - & $\begin{array}{l}\text { Bioseed } 9681 \\
\text { (Check) }\end{array}$ & India & NA \\
\hline
\end{tabular}

NA- not available

The 22 inbred lines, 40 line $\mathrm{x}$ tester crosses progenies and 4 check varieties were evaluated in a Randomized Complete Block Design (RCBD) with three replications each plot consisted of two rows of $5 \mathrm{~m}$ long and the row to row and plant to plant distance was $75 \mathrm{~cm}$ and $25 \mathrm{~cm}$, respectively. The net area of individual plot is $1.5 \mathrm{~m} \times 5 \mathrm{~m}$ i.e. $7.5 \mathrm{~m}^{2}$. There were 42 plants in each plot and the inner five plants were selected for observations.

The phenological traits; days to $50 \%$ silking (DTS), days to $50 \%$ tasseling (DTT) and days to maturity (DTM), quantitative traits; plant height $(\mathrm{PH})$, ear height $(\mathrm{EH})$ and yield attributing traits; number of rows per cob (NRC), number of kernels per row (NKR), thousand kernels weight (TKW), grain yield (GY) and shelling percentage (SHP) data were recorded. 


\section{Results and discussion}

\section{Inbred lines characterization}

Quantitative and qualitative characterization of maize inbred lines was done in winter season. Inbred line, RL-180 was susceptible to army worm and stem borer and yellow green in leaf color, yellow anther color. The two testers, RL-84 and RML-17 had open type of tassel, RL-94, RML-32 and RL-36 had close type of tassel. Bacterial leaf sheath blight was prominent in L-1 inbred line. There were variations in the incidence of disease and insect pests. There was low incidence of disease and insect pest in spring season.

\section{Chlorophyll content}

The average values of Area under SPAD value retreat curve (AUSRC) measurement of maize green leaf had ranged from 359.07 to 515.1 The Average AUSRC values of green leaf of maize inbred line, RL-180 was found lowest and RL-100 was found highest at all stages of maize. The different inbred lines had AUSRC values because they might be derived from different genetic bases. Physiological evidences indicate that loss of chlorophyll during grain filling period is associated with reduced yield in the field (Reynolds et al., 1994).

\section{Mean analysis}

Highly significant grain yield was recorded among treatments. The average mean of grain yield for parental inbred was $1547.16 \mathrm{~kg} / \mathrm{ha}$ ranging from $381.5 \mathrm{~kg} / \mathrm{ha}$ in RL-21 to $3977 \mathrm{~kg} / \mathrm{ha}$ in RL180.The average mean of grain yield for hybrids was found $5741.6 \mathrm{~kg} / \mathrm{ha}$ ranging from $15870 \mathrm{~kg} / \mathrm{ha}$ in RML-32 x RML-17 to $1519 \mathrm{~kg} / \mathrm{ha}$ in RL- $36 \times$ RL-84. The average mean of grain yield for checks was found $6272.5 \mathrm{~kg} / \mathrm{ha}$ ranging from $3622 \mathrm{~kg} / \mathrm{ha}$ for Arun-2 to $7610 \mathrm{~kg} / \mathrm{ha}$ for Gaurav. The over all average mean of grain yield was found $5387.34 \mathrm{~kg} / \mathrm{ha}$. The average mean yield of grain yield of hybrids or crosses were found higher parent mean that means that there is wide scope of obtaining potential high yielding hybrids.

The early maturing parents were RL-194 (84 DAS), RML-41 (84 DAS), RL-84 (84 DAS), PUTU16 (85 DAS) on the basis of days to $50 \%$ siliking. The mean values for days to $50 \%$ silking of hybrids was 79 DAS which was earlier than the parents (90 DAS) and checks (84 DAS), respectively. PUTU-16 x RL-84 (76 DAS), RML-3 X RML-17 (78 DAS), L5 $x$ were earlier on the basis of days to $50 \%$ silking. 
Table 2. Mean squares from ANOVA of different traits of maize at Rampur, Chitwan in 2008/09

\begin{tabular}{lllllll}
\hline Source & DF & $\begin{array}{l}\text { No. of rows } \\
\text { per cob }\end{array}$ & $\begin{array}{l}\text { Days to } \\
\mathbf{5 0 \%} \\
\text { silking }\end{array}$ & $\begin{array}{l}\text { Thousand } \\
\text { kernel } \\
\text { weight }\end{array}$ & $\begin{array}{l}\text { Shelling } \\
\text { percentage }\end{array}$ & Grain yield \\
\hline Replication & 2 & 1.702 & 37.354 & 2576.066 & 108.478 & 52314548.131 \\
Treatment & 65 & $4.781^{* *}$ & $76.06^{* *}$ & $3592.81^{* *}$ & $46.326^{* *}$ & $32945390.75^{* *}$ \\
Error & 130 & 1.056 & 8.020 & 1131.025 & 295.252 & 9670141.612 \\
Total & 197 & & & & & \\
CV\% & & 8.09 & 3.40 & 10.65 & 9.90 & 37.72 \\
GM & 12.70 & 84 & 315.68 & 68.78 & 5387.49 \\
Parent mean & 11.75 & 90 & 306.65 & 60.17 & 1547.16 \\
Hybrid mean & 13.15 & 81 & 321.93 & 73.28 & 5741.60 \\
Check mean & 13.33 & 81 & 26.33 & 71.05 & 6272.50 \\
\hline
\end{tabular}

*Significance at 0.05 level of significance; ${ }^{* *}$ Significance at 0.01 level of significance; cv\%coefficient of variation.

\section{Heterosis analysis}

The highest yielding hybrid was RML-32 x RML-17 having grain yield $15870 \mathrm{~kg} / \mathrm{ha}$, followed by RL-194 x RL-84 (10770 kg/ha), RML-21 x RML-17 (9270 kg/ha), RL-180 x RML-17 (9270 kg/ha) and L-1 x RL-84 (8785 kg/ha). All the crosses had shown negative heterosis for days to $50 \%$ silking ranging from RML-64 x RL-84 (-4.65\%) to PUTU-18 x RML-17 (-16.23\%) indicating that these were earlier than parents. The early maturing hybrids were PUTU-18 x RML-17 (-16.23\%), RML32 x RML-17 (-13.33\%), L-20 x RL-84 (-11.86\%) and PUTU-18 x RL-84 (-11.83\%), respectively. Thirty nine hybrids showed positive heterosis for grain yield among the 40 crosses. The best positive mid-parent heterosis was found $880 \%$ in cross between RML-32 and RML-17, followed by RL-98 x RML-17 (507\%), RL-103 x RML-17 (403\%), PUTU-18 x RML-17 (351\%), RL-180 x RL84 (316\%) and RL-180 x RML-17 (303\%), respectively.

\section{GCA analysis}

The highest negative GCA effects for days to 50\% silking was found in RL-103 (-255), followed by RML-24 (-250), RL-180 (-235), L-1 (-225), L-20 (-207), RL-100 (-204), RML-32 (-196), RML-41 (-191), PUTU-16 (-187), RL-36 (-181), RL-194 (-181), RL-98 (-58) and RL-194 (-54), respectively. The inbred lines L-1 (1414), L-20 (1027), RML-24 (930), RL-103 (79) and RL-100 (39) had showed the positive GCA value for number of rows per cob. The highest GCA value for shelling $\%$ was observed in L-1 (1790) followed by PUTU-16 (1430), RML-64 (1013) and RL- 98 (337) among 40 crosses. The good combiners for 1000 grain weight were L-1 (1208), RML- 64 (616), PUTU-16 (372), RML-41 (86), RL-98 (66) and RL-36 (52) among 20 inbred lines. 
Table 3. Classification of hybrids on the basis of heterosis at Rampur, Chitwan, 2008/09

\begin{tabular}{|c|c|c|c|}
\hline & Higher heterosis & Heterosis & Negative heterosis \\
\hline DTS & - & - & $\begin{array}{lllll}\text { PUTU 18 } & \text { X } & \text { RML } & 17 \\
(-16.23 \%) & & & \end{array}$ \\
\hline PH & $\begin{array}{l}\text { RL } 17 \text { X } \\
(70 \%)\end{array}$ & $\begin{array}{l}\text { RL } 17 \text { X RL } 84 \text { (66\%), L } 5 \text { X RL } \\
84(65 \%) \text {, RML 5X RL } 84 \text { (64\%) }\end{array}$ & - \\
\hline $\mathrm{EH}$ & $\begin{array}{l}\text { RL } 21 \\
(85 \%)\end{array}$ & $\begin{array}{l}\text { RML } 64 \text { X RML 17(71\%), RML } \\
64 \text { X RL } 84(66 \%)\end{array}$ & - \\
\hline NRC & $\begin{array}{l}\text { RL } 180 \text { X RML } 17 \\
(47 \%)\end{array}$ & RL 100 X RL $84(40 \%)$ & RL 180 X RML 17 (-8\%) \\
\hline NKR & $\begin{array}{l}\text { RL } 100 \times \text { RML } 17 \\
(114 \%)\end{array}$ & $\begin{array}{l}\text { RL } 100 \text { X RL } 84 \text { (113\%), L 5X } \\
\text { RML } 17(106 \%) \text {, }\end{array}$ & RL 180 X RL 84 (-24\%) \\
\hline SHP & L 5 X RML 17 (53\%) & $\begin{array}{l}\text { RL 98X RML } 17 \text { (50\%), RML } \\
\text { 32X RML } 17(38 \%)\end{array}$ & RL 180 X RL 84 (-17\%) \\
\hline TKW & $\begin{array}{l}\text { RL } 17 \text { X } \\
(28 \%)\end{array}$ & $\begin{array}{l}\text { RML } 5 \text { X RML } 17 \text { (27\%), L } 1 \text { X } \\
\text { RML } 17 \text { (21\%), RML } 64 \text { X RML } \\
17(17 \%)\end{array}$ & RL 107 X RL 84 (-31\%) \\
\hline GY & $\begin{array}{l}\text { RML } 32 \text { X RML } 17 \\
(880 \%)\end{array}$ & $\begin{array}{l}\text { RL 98X RML } 17(507 \%) \text {, RL } 103 \\
\text { X RML } 17(403 \%) \text {, PUTU } 18 \text { X } \\
\text { RML } 17(351 \%), \text { RL } 180 \text { X RL } 84 \\
(316 \%)\end{array}$ & RL 36 X RL 84 (-36\%) \\
\hline
\end{tabular}

Table 4. Classifications of inbred parents on the basis of GCA values at Rampur, Chitwan, 2008/09

\begin{tabular}{|c|c|c|c|}
\hline \multicolumn{4}{|c|}{ General Combiners } \\
\hline & Best & Good & Poor \\
\hline DTT & PUTU 18 (678) & $\begin{array}{l}\text { RML 64, RL 21, RL 17, RL 194, RL } \\
98\end{array}$ & L 20, RL 103, RML 24 \\
\hline DTS & RML 64 (1246) & L 5(595), PUTU 18 (337) & $\begin{array}{l}\text { RL } 103 \text { (-255), RML } 24 \\
(-250), \text { RML } 32 \quad(-196)\end{array}$ \\
\hline PH & RML 32 (1089) & PUTU 18 (952), L 5 (256) & RL 107(-303), L $1 \quad$ (-272) \\
\hline NRC & L 1 (1414) & $\begin{array}{l}\text { L } 20 \text { (1027), RML } 24 \text { (930), RL } \\
\text { 103(79), RL } 100(39)\end{array}$ & L 5 (-305), RL $194 \quad(-305)$ \\
\hline SHP & L 1 (1790) & $\begin{array}{l}\text { PUTU 16(1430), RML 64(1013), RL } \\
\text { 98(337) }\end{array}$ & RL 21(-365), RML 5 (-363) \\
\hline TKW & L 1(1208) & $\begin{array}{l}\text { RML } 64 \text { (616), PUTU } 16 \text { (372), } \\
\text { RML } 41 \text { (86), RL } 98 \text { (66) }\end{array}$ & $\begin{array}{l}\text { RML } 32 \text { (-229), RL } 94 \\
(-227)\end{array}$ \\
\hline GY & RML 64 (1201) & $\begin{array}{l}\text { L } 5 \text { (1174), PUTU } 16 \text { (815), RML } \\
41(282), \text { RL } 194 \text { (211) and RL } 36 \\
(55)\end{array}$ & $\begin{array}{l}\text { RL } 94(-340), \text { RML } 32 \\
\begin{array}{ll}(-339), \text { RL } 100 \quad(-309)\end{array}\end{array}$ \\
\hline
\end{tabular}


Similar, GCA effect for grain yield also reported by; Koirala and Gurung (2002) in seven yellow maize populations and Pandey (2009) also revealed similar results on tropical, subtropical and temperate maize germplasm range from TZ i- 25 (-829) to $69 \mathrm{~B}(561)$.

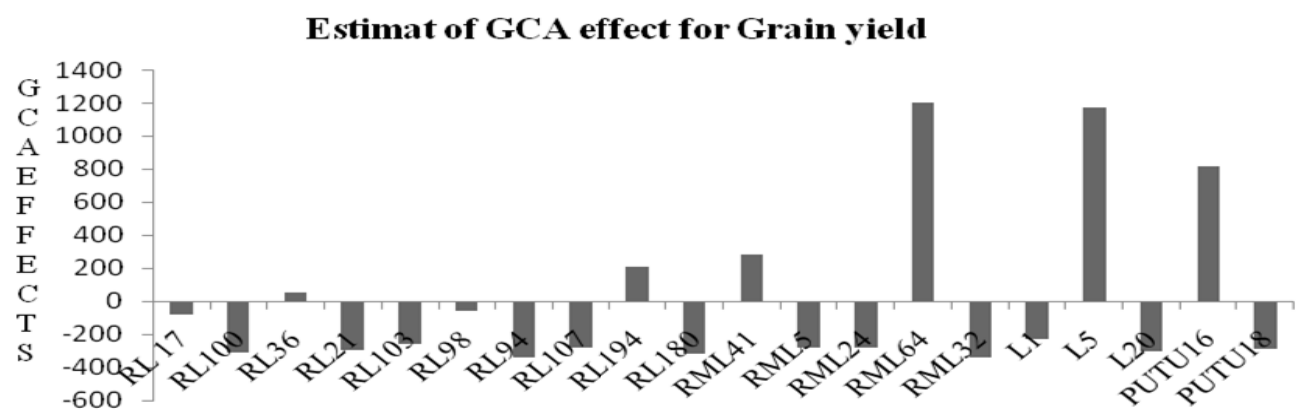

\section{SCA analysis}

Nepalese Yellow Maize inbred lines

Eleven hybrids exhibited positive SCA effects while the 29 crosses showed negative SCA effects among 40 cross hybrids for days to $50 \%$ silking. The crosses with the positive SCA effects were L-1 x RL-84 (2326), L-20 x RL-84 (1666), L-1 x RML-17 (1414), L-20 x RML-17(1027) for number of rows per cob. The good specific combiners were RML-64 x RML- 17 (1201.89), L-5 x RML-17 (1174.23), RML- 41 x RL 84 (865.37), PUTU-16 x RML-17 (815.16), RL-36 x RL- 84 (548.99), RML-41 x RML-17 (282.64) and RL-194 x RML-17 (211.01), respectively.

Table 5. Classification of the hybrids on the basis of SCA values at Rampur, Chitwan, 2008/09

\begin{tabular}{|c|c|c|c|}
\hline \multicolumn{4}{|c|}{ Specific Combiners } \\
\hline & Best & Good & Poor \\
\hline DTS & $\begin{array}{l}\text { RML 64 RML } \\
17(1900)\end{array}$ & RML 64 X RL 84 (1246),L5 X RL 84(1055) & $\begin{array}{l}\text { PUTU } 18 \text { X RL } 8 \\
(-761), \text { RL } 21 \quad \text { X } \\
\text { RL 84(-583) }\end{array}$ \\
\hline $\mathrm{PH}$ & $\begin{array}{l}\text { PUTU } 18 \quad X \\
\text { RL } 84(1167)\end{array}$ & L 5 X RL 84 (1304), RML 32 X RML 17 (1089) & $\begin{array}{l}\text { RML } 32 \text { X RL } 84 \\
(-1999), \text { RL } 94 \text { X } \\
\text { RL } 84(-346)\end{array}$ \\
\hline EH & $\begin{array}{l}\text { PUTU } 18 \quad X \\
\text { RL } 84(1308)\end{array}$ & $\begin{array}{l}\text { RML } 32 \text { X RML } 17 \text { (1089), RML } 5 \text { X RL } 84 \\
\text { (1064) }\end{array}$ & $\begin{array}{l}\mathrm{L} 20 \times \mathrm{xL} \quad 84 \\
(-1445)\end{array}$ \\
\hline NRC & $\begin{array}{l}\text { L } 1 \text { X RL } 84 \\
(2326)\end{array}$ & L20 X RL 84 (1666), L 1 X RML 17 (1414) & RML $24(-1628)$ \\
\hline SHP & $\begin{array}{l}\text { L } 1 \text { X RL } 84 \\
(3025)\end{array}$ & L 1 X RML 17 (1790), RML 64 X RML 17 (1013) & $\begin{array}{l}\text { RML } 41 \text { X RL } 84 \\
(-2030.27)\end{array}$ \\
\hline GY & $\begin{array}{l}\text { RL } 194 \text { X RL } \\
84(1619.41)\end{array}$ & $\begin{array}{l}\text { RML } 64 \text { X RML } 17 \text { (1201.89), L } 5 \text { X RML } 17 \\
\text { (1174.23), RML } 41 \text { X RL } 84 \text { (865.37), PUTU } 16 \text { X } \\
\text { RML 17 (815.16), RL 36 X RL } 84 \text { (548.99), } \\
\text { RML41X RML17(282.64) }\end{array}$ & $\begin{array}{ll}\text { RL } & 94 \quad(-340) \\
\text { RML } & 32(339), \\
100 \\
(-309)\end{array}$ \\
\hline
\end{tabular}


Gurung (2006) reported that the range of SCA effects from -1967.98 to1852.24 in Nepalese maize varieties studies. Koirala and Gurung (2002) found also similar results in yellow maize population studies. Melani et al.,(2005) found that the proportion of sum of squares due to SCA effects was $17 \%$. Xingming et al., (2001) found the range of the SCA effects for grain yield from -1670.90 to 1813.50 in Chinese yellow grain QPM inbred lines. Beck et al., (1991) also found significant positive SCA effects in CIMMYT's subtropical and temperate intermediate maturity maize germplasm. Pandey (2009) reported the range of SCA values from RL 111 x 69 B (-1899) to RML 8 X P 45 (1606).

\section{Summary and conclusion}

Significant differences observed among the treatments for most of traits which indicates presence of genetic variability and high magnitude of heterosis among crosses and their parents. Characterizations of maize inbred lines were carried out on the basis of qualitative and quantitative traits. Chlorophyll content \{Area under SPAD value retreat curve (AUSRC) $\}$ of leaves was measured at 45 DAS, 55 DAS and 65 DAS to determine the physiological aspects of inbred lines. The crosses between RML-32 and RML-17 had found the highest grain yield $(15870 \mathrm{~kg} / \mathrm{ha})$ followed by, RL-194 x RL- 84 (10770 kg/ha), RML-21 x RML-17 (9270 kg/ha), RL-180 x RML-17 $(9270 \mathrm{~kg} / \mathrm{ha})$ and L-1 x RL-84 (8785 kg/ha), respectively, were promising hybrids on the basis of grain yield. The selection of shelling percentage, number of kernels per row and number of rows per cob will be useful to increase the grain yield of maize on the basis of strong correlation of these traits with grain yield. Promising and early maturing hybrids need to be put into different experimental stages of evaluation. Parents having the high negative GCA values and parents of the crosses showing high negative heterosis and SCA effects for days to $50 \%$ silking could be utilized as ideal parents for developing early maturing hybrids. Parents having the high negative GCA values and negative heterosis and SCA effects for plant height may be utilized for reducing plant heighthe selection of traits for shelling percentage, number of kernels per row and number of rows per cob will be useful to increase the grain yield of maize because grain yield had strong positive correlation with these traits. The promising hybrids need to be put into different experimental stages of evaluation. Therefore, NMRP need to utilize best performing inbred lines for developing early and high yielding hybrids.

\section{Acknowledgement}

Authors would like to express their thanks to the National Agriculture Research Development Fund (NARDF), Singh Durbar Plaza for research fund, NMRP maize breeding team for providing the technical suggestions and research materials. 


\section{Literature cited}

Adhikari, K. 2007. Maize in Nepal: Research Achievements (2004-2006) for Food and Feed Security and Livelihood Improvement. In: D.B. Gurung, D.C. Paudel, G. K.C., S.R. Upadhyay and B.B. Pokhrel (eds.). Proceeding of the $25^{\text {th }}$ National Summer Crops Research Workshop on Maize Research and Production in Nepal, held in June 21-23, 2007, at national Agriculture Research Institute, NARC, Khumaltar, Lalitpur, Nepal. pp. 1-6.

Beck, DL, SK Vasal and J Crossa. 1991. Heterosis and combining ability among subtropical and temperate intermediate maturity maize germplasm. Crop Science 3:68-73

Gurung, DB. 2006. Genetic diversity, heterosis and combining ability within Nepalese maize varieties. Thesis, Ph.D. Central Luzon State University, Science of Munoz, Nueva Ecija, Philippines. $171 \mathrm{p}$.

Koirala, KB and DB Gurung. 2002. Heterosis and combining ability of seven yellow maize populations in Nepal. Proceedings of the $8^{\text {th }}$ Asian Regional Maize Workshop held August 5-8, 2002, Bangkok, Thailand.

Melani, MD and MJ Carena. 2005. Alternative maize heterotic patterns for the Northern Corn Belt. Crop Science 45:2186-2194.

Ministry of Agriculture and Cooperative. 2008. Selected indicators of Nepalese agriculture and population. Government of Nepal. Ministry of Agriculture and Cooperative, Agri-Bussiness Promotion and Statistics Division, Singh Darbar, Kathmandu, Nepal.

Pandey, BR. 2009. Genetic analysis of Tropical, Subtropical and Temperate Maize (Zea mays L.) Germplasm. Thesis, M.Sc. Agriculture. The Graduate School Kyungpook National University, Korea. 44 p.

Reynolds, MP, M Balota, MIB Delgado, I Amani, and RA Fischer. 1994. Physiological and morphological traits associated with spring wheat yield under hot irrigated conditions. Australian Journal Plant Physiology 21: 717-730.

Sharma, D. 2003. Heterosis and combining ability of Nepalese yellow maize germplasm. Thesis, M. Sc. Ag. Institute of Agriculture and Animal Science, Tribhuvan, University, Rampur, Chitwan, Nepal. $82 \mathrm{p}$.

Xingmimg, F, TJH Bihua and L Feng. 2001. An analysis of combining ability and heterotic groups of yellow grain quality protein maize inbreds. Proceedings of the Seventh Eastern and Southern Africa Regional Maize Workshop. Pp 143-148. 